\title{
Roles Assigned to Heritage Learners in Beginner Spanish Mixed Classes*
}

\author{
YULY ASENCIÓN-DELANEY**
}

How to cite this article: Asención-Delaney, Y. (2020). Roles Assigned to Heritage Learners in Beginner Spanish Mixed Classes. Cuadernos de Lingüística Hispánica, (36), 135-153.

(đi) $10.19053 / 0121053 X . n 36.2020 .11230$

\section{* Research article.}

** Spanish Professor in the Department of Global Languages and Cultures at Northern Arizona University. She holds a Ph.D. in Applied Linguistics from Northern Arizona University and her main research interests include writing in a second language, language assessment, teaching Spanish heritage speakers and the use of technology in the language classroom. E-mail: Yuly. Asencion@nau.edu @https://orcid.org/0000-0002-7720-6897 


\section{Abstract}

Recent data indicate that there is a large population of Spanish Heritage Learners (HLs) in postsecondary institutions in the U.S. (National Center for Education Statistics [NCES], 2017). However, only 40\% of institutions offer at least one course for this student population (Beaudrie, 2012). This situation forces HLs to take language courses designed for Spanish second language learners (i.e., mixed classes). This article reports a study that was carried out to answer the following research questions: a) what roles do instructors assign to HLs in their beginner classes, and b) how do these observed roles support the HL language instruction goals and meet their needs for cultural connection? Results indicate that teachers assign a variety of roles to heritage learners in their beginner Spanish classes. These roles include serving as a language model or informant in terms of linguistic, pragmatic or cultural knowledge, translating and tutoring. The assigned roles could support or inhibit heritage learners' linguistic and cultural goals depending on their linguistic level. This article concludes with a discussion of the implications of these findings as they pertain to the required teacher training to better serve these learners in mixed language classes.

Keywords: student's role, languages teaching, heritage learners.

\section{Roles asignados a los aprendices de español como lengua heredada en las clases mixtas para principiantes}

\section{Resumen}

Datos recientes indican que hay una gran población de aprendices de español como lengua heredada en instituciones universitarias en los Estados Unidos (National Center for Education Statistics [NCES], 2017). Sin embargo, solo el $40 \%$ de las instituciones ofrecen al menos un curso para estos estudiantes (Beaudrie, 2012). Esta situación obliga a los hablantes de herencia a tomar cursos de lenguas diseñados para aprendices de español como segunda lengua, clases mixtas. Este artículo reporta un estudio llevado a cabo para responder a las siguientes preguntas de investigación: a) ¿Cuáles son los roles que los instructores asignan a los hablantes de herencia en las clases para principiantes?, y b) ¿Cómo los roles asignados apoyan el logro de sus metas instruccionales de lengua y satisfacen sus necesidades de conexión cultural? Los resultados indican que los profesores asignan una variedad de roles a los hablantes de herencia: servir como modelo o informante lingüístico, pragmático y cultural, traductor y tutor. Estos roles podrían apoyar o inhibir las metas lingüísticas y culturales de los hablantes de herencia dependiendo de su nivel lingüístico. Este artículo concluye con una discusión de las implicaciones de estos resultados en relación con la formación del profesorado requerida para servir mejor a estos estudiantes en las clases mixtas.

Palabras clave: papel del estudiante, enseñanza de idiomas, hablantes de herencia. 


\section{Rôles attribués aux apprenants d'espagnol langue maternelle dans les cours mixtes pour débutants}

\section{Résumé}

Des données récentes indiquent qu'il existe un grand nombre d'apprenants d'espagnol, langue maternelle, dans les universités aux États-Unis (NCES, 2017). Cependant, seulement le $40 \%$ offrent au moins un cours à ces étudiants (Beaudrie, 2012). Cette situation les oblige à suivre des cours de langue organisés à l'intention des apprenants d'espagnol langue seconde: des cours mixtes. Cet article présente une étude réalisée pour répondre aux questions de recherche suivantes: a) Quels sont les rôles que les enseignants attribuent aux apprenants dont la langue maternelle est l'espagnol dans les classes pour débutants? Et b) Dans quelle mesure ces rôles appuient la démarche pédagogique qui leur permet d'atteindre les objectifs d'apprentissage et de répondre aux besoins de rapports culturelles? Les résultats indiquent que les enseignants attribuent une variété de rôles aux apprenants de langue maternelle, à savoir: jouer le rôle de guide linguistique, pragmatique et culturel, de traducteur et de tuteur. Ces rôles pourraient entretenir ou estomper les objectifs linguistiques et culturels des apprenants hispanophones en rapport à leur niveau linguistique. Cet article se termine par une discussion, autour des données de ces résultats à l'encontre de la formation des enseignants, nécessaire pour mieux répondre aux besoins et aux atteintes des élèves dont la langue maternelle est l'espagnol dans les classes mixtes.

Mots-clés: rôle des étudiants, enseignement des langues, apprenants dont la langue maternelle est l'espagnol, Rôles attribués aux apprenants d'espagnol en tant que langue maternelle dans les classes mixtes pour débutants.

\section{Papéis atribuídos aos que aprendem espanhol como idioma herdado em classes mistas para iniciantes}

\section{Resumo}

Dados recentes indicam que existe uma grande população de aprendizes de espanhol como idioma herdado em instituições universitárias nos Estados Unidos (NCES, 2017). No entanto, apenas 40\% das instituições oferecem pelo menos um curso para esses alunos (Beaudrie, 2012). Essa situação obriga os palestrantes a fazer cursos de idiomas projetados para alunos do espanhol como segundo idioma, em aulas mistas. Este artigo relata um estudo realizado para responder às seguintes perguntas de pesquisa: a) Quais são os papéis que os instrutores atribuem aos palestrantes em aulas 
para iniciantes? E b) Como os papéis atribuídos estão apoiando o desempenho dos seus objetivos instrucionais de idioma e atender às suas necessidades de conexão cultural? Os resultados indicam que os professores atribuem uma variedade de papéis aos falantes de patrimônio, servindo como modelo o informante linguístico, pragmático e cultural, tradutor e tutor. Esses papéis podem apoiar ou inibir os objetivos linguísticos e culturais dos falantes do patrimônio, dependendo do nível do idioma. Este artigo conclui com uma discussão das implicações desses resultados em relação à formação de professores necessária para melhor atender esses alunos em turmas mistas.

Palavras-chave: papel do aluno, ensino de idiomas, falantes de patrimônio.

\section{Introduction}

Recent data indicate that there is a large population of Latinos in colleges around the U.S. Between the years 2005 and 2015, Hispanic enrollment between the ages of 18 and 24 in undergraduate programs increased from $25 \%$ to $37 \%$. As a whole, the Hispanic population enrollment in higher education institutions doubled from 1.4 million in 2000 to 3 million in 2014 (NCES, 2017). Even though this student population continues to grow, there are few higher education institutions that offer language courses specifically developed for Spanish Heritage Learners (HLs). Some researchers have reported foreboding statistics about these programs that are not promising in regards to addressing the language education needs of this student population. For example, Beaudrie (2012) reported that merely $40 \%$ of Spanish programs in 422 universities offered courses for this population of learners.

Although the number of classes for Spanish HLs has increased, the majority of them are developed for learners with high oral proficiency in Spanish who have not received formal instruction in Spanish, thus ignoring a large number of HLs that are receptive bilinguals. Often characterized by low proficiency skills in writing and speaking, these learners would like to increase their linguistic abilities and fluency, as well as to develop their identity as heritage speakers and their connections to the heritage culture (Beaudrie \& Ducar, 2005).

It is the case that these students are usually motivated to learn Spanish, so they frequently enroll in Spanish courses for beginners designed for second language (L2) learners (i.e., mixed classes) with different configurations: mixed classes with few HLs, a balanced number of HLs and L2 learners, or a large number of HLs (Carreira, 2014). Regardless of the configuration, mixed classes have been deemed as not appropriate for HLs because they have different linguistic and affective needs as well as a desire to 
connect with the heritage culture that the L2 students do not have (Carreira, 2014; Felix, 2009; Potowski, 2002). In spite of having HL and Spanish L2 students with different educational needs in mixed classes, some researchers argue that mixed classes could still help the receptive bilingual HL to develop his or her Spanish linguistic skills (Beaudrie, 2009; Carreira, 2014) if these courses are centered on topics and experiences related to the Hispanic population in the United States, focus on linguistic forms useful for the HL as well as the 22 learners, implement a macro-based approach in which instruction begins with meanings associated with authentic materials first rather than grammatical forms, and uses differentiated instruction. Although there maybe benefits on the interactions between HL and L2 learners or differentiated instruction in mixed Spanish courses, it is worth noting that HLs linguistic practices and needs should be validated on their own rather than supplanted or supplemented with a more standardized variety of Spanish (Rosa, 2019). Teachers and their practices in mixed classes could perpetuate the perception of HLs as a deficient linguistic group in Spanish, so it is important to be aware of how we are positioning these students in our instructional context.

In order to understand the nature of instruction in mixed classes, a group of studies has explored the students' and teachers' perceptions of different aspects of mixed classes. From the students' point of view, studies like the ones by Bowles (2011), Bowles and Montrul (2014), Burgo (2019), Campanaro (2013), Dones-Herrera (2015) and Edstrom (2007) report that HLs have positive attitudes toward working in groups with L2 learners in which they can learn from L2 learners and help them with their language concerns. These kinds of interactions position HLs as language experts, which may contribute to an increase in their linguistic confidence ( Blake \& Zyzik, 2013). Other researchers, however, have found that the Spanish L2 learners could feel intimidated when working with HLs, and some HLs could have the perception that they usually do most of the work in group activities (Leeman \& Serafini, 2017). In addition, Burgo (2019), Felix (2009) and Potowski (2002) noted that HLs could also feel marginalized by their L2 classmates when they feel that the Spanish L2 learners have better control of grammar and writing skills, and embarrassed when instructors and L2 learners have higher expectations for them in regards to their linguistic level, causing them to worry about not being able to meet those expectations.

From the Spanish instructors' perspective, mixed classes pose different challenges on how to address the needs of both L2 learners and HLs. College instructors in studies by Bello (2014) and Campanaro (2013) believe that having HL and L2 learners is a positive experience because the L2 learners can be exposed to different Spanish accents and the L2 culture, and HLs can help the L2 learners. However, they recognized that 
the L2 learners could feel intimidated because they perceive the HLs as more advanced and better at speaking. Moreover, Lacorte and Canabal (2005) pointed out that college language instructors should be aware of the effect of their own ideology, identities, attitudes and beliefs about FL teaching and HLs regarding the dynamics between the HLs and their instructors and peers.

At the high school level, teachers surveyed in Boyd (2002) and Russell and Kuriscak (2015) also believe that there may be advantages to the interactions between L2 learners and HLs in mixed classes, but pointed out that the main issues of working with mixed classes include linguistic issues related to the knowledge and use of language (e.g., dialectal variation, spelling and writing skills), social and identity issues (e.g., assuming the HLs know Spanish already), and curricular issues on how to integrate strategies, materials, and assessments that support HLs with varying levels of Spanish language proficiency. Furthermore, Randolph (2017) added that high school Spanish teachers may interact differently with L2 learners vs. HLs, using advanced Spanish and establishing linguistic authority with HLs while using teacher talk with L2 learners.

Although the research reviewed above has provided hints on the possible roles HLs play in mixed classes, no study has explored in depth the specific roles as assigned by teachers, especially in beginner classes and how they support the heritage language instruction goals and meet their needs for cultural connection at this level. AsenciónDelaney (2019), after analyzing the annotations for heritage speakers in introductory Spanish textbooks and observing that certain roles (i.e., linguistic, pragmatic and cultural informants, linguistic model, and input provider) were suggested in these annotations, calls for the need to validate these suggestions by collecting data from teachers and classroom observation. Responding to this need, and in order to contribute to a better understanding of the role of HLs in college beginner mixed Spanish courses, this study seeks to validate the information about the roles assigned to HLs inferred from previous research by collecting direct data from teachers to answer the following research questions: a) what roles do instructors assign to HLs in their beginner classes? and b) how do the observed roles support the HL language instruction goals and meet their needs for cultural connection?

\section{Methods}

This section presents information about the participants of the study, the variables (i.e., the roles analyzed), and the procedures used for data collection and analysis. 


\section{Participants}

Data for this study came from twenty-two instructors teaching lower-division courses in a Spanish college program in the Southwest (see Table 1). The sample of the instructors included fourteen female and eight male teachers with teaching experience ranging from three months to thirteen years. Seventeen instructors were graduate teaching assistants while four were lecturers, and one was a part-time instructor. Both lecturers and part-time instructors hold at least a Masters' degree in Teaching Spanish, but the lecturers usually teach 24 credit hours a year, while part-timers only teach up to 7.5 credit hours a semester. Eleven instructors were native speakers of English, eight were native speakers of Spanish, and three were heritage speakers of Spanish. Only four instructors had some training in teaching Spanish HLs via a graduate course on the topic or completing professional development activities related to this group of learners.

Table 1. Instructors

\begin{tabular}{lllll}
\hline Instructors & Gender & Spanish & $\begin{array}{l}\text { Years of } \\
\text { Experience }\end{array}$ & $\begin{array}{l}\text { Training } \\
\text { Teaching HL }\end{array}$ \\
\hline $\begin{array}{l}\text { Graduate teaching } \\
\text { assistants }\end{array}$ & $\mathrm{F}=10$ & $\mathrm{~L} 2=7$ & 3 months -3 & Yes $=2$ \\
$(\mathrm{~N}=17)$ & $\mathrm{M}=7$ & $\mathrm{~L} 1=7$ & years & No $=15$ \\
& & $\mathrm{HS}=3$ & & \\
$\begin{array}{l}\text { Lecturers } \\
(\mathrm{N}=4)\end{array}$ & $\mathrm{F}=3$ & $\mathrm{~L} 2=3$ & $4-13$ years & $\begin{array}{l}\text { Yes }=1 \\
\text { M }=1\end{array}$ \\
$\begin{array}{l}\text { Part-time } \\
\text { instructors } \\
(\mathrm{N}=1)\end{array}$ & $\mathrm{F}=1$ & $\mathrm{~L} 2$ & 2 years & Yes $=1$ \\
\hline
\end{tabular}

\section{Description of Roles Assigned to HLs}

The list of roles assigned to HLs used in this study was derived from previous studies on HLs and their teachers. These roles were:

a. Input provider: HLs provide oral or written input in Spanish (e.g., describe a person, narrate an event) so that the rest of the students ask or answer questions about the input (Asención-Delaney, 2019). 
b. Linguistic model: In this role, the HL is asked to read aloud or say something in Spanish so that the rest of the students can imitate or pay attention to the pronunciation (Al Masaeed, 2014; Asención-Delaney, 2019; Belpoliti, 2017; Lacorte \& Canabal, 2005).

c. Linguistic informant: Teachers usually ask HLs to provide words or linguistic expressions often used in their variety of Spanish (Asención-Delaney, 2019; Felix, 2009; Randolph, 2017).

d. Cultural informant: HLs could be asked to describe the products, practices and perspectives of their Hispanic heritage cultural group (Al Masaeed, 2014; Asención-Delaney, 2019; Bello, 2014; Russell \& Kuriscak, 2015).

e. Pragmatic informant: In this role, HLs are asked to comment on the appropriate context of use for certain linguistic expressions or forms (Asención-Delaney, 2019).

f. Translator/Interpreter: For this role, HLs are asked to translate instructions or information provided in Spanish into English. They can also provide the Spanish equivalent of an English word or expression (Felix, 2009).

g. Tutor/Helper: HLs can be asked to help L2 learners or tutor students that are having problems in the class (Belpoliti, 2017; Bowels \& Montrul, 2014; Campanaro, 2013; Dones-Herrera, 2015; Edstrom, 2007; Russell \& Kuriscak, 2015).

\section{Instruments and Procedures}

This study used different sources of information to answer the research questions. These procedures accounted for not only the roles the Spanish instructors perceived that they assign to the HLs in their classes, but also what they actually said and did in the classroom. Therefore, three sources of information were used to collect the data: guided interviews, a questionnaire, and non-participant class observations.

The 22 participants were interviewed by the researcher using a set of nine questions related to their experience with HLs in their classes and the advantages and disadvantages of having these learners in beginner classes designed for L2 learners of Spanish. The interviews were recorded and later transcribed to facilitate the identification of the roles assigned to the HLs from the instructors' answers. 
The Spanish teachers also completed a questionnaire. The questionnaire consisted of two parts. The first part collected demographic information about the participants and information about the number of HLs they had in their classes. The second part included 25 statements about practices and perceptions of HLs in beginner Spanish classes (e.g., "I ask HLs to pronounce new words and forms in Spanish to make the class aware of regional differences in Spanish pronunciation".). Some of the statements were created or adapted from instruments used in other related studies (e.g., Al Masaeed, 2015; Bello, 2014). The participants used a 4-point Likert scale to express their agreement or disagreement with the statements $(1=$ Strongly disagree, $2=$ Disagree, $3=$ Agree, and $4=$ Totally Agree). Items with means of 2.5 or above were considered to provide evidence of teachers assigning the role to their HLs.

To triangulate the information provided in the interviews and the questionnaire, non-participant class observations were conducted in 11 beginner classes that had three or more HLs. The class observations were guided by a form in which the researcher collected information about the class and recorded the frequency of the roles the instructor assigned to the HLs during the session.

\section{Results}

This section presents the findings for the different roles assigned to the HLs by their Spanish instructors in beginner Spanish mixed classes. The findings present quantitative and qualitative evidence collected from the three sources of information used: the questionnaire, interviews, and class observations. First, the results from the questionnaire are presented in Table 2 and then compared with the qualitative evidence collected from the interviews and class observations for each role.

Table 2. Roles Assigned to HLs by Instructors

\begin{tabular}{ll|c|c}
\hline Role & Mean & SD \\
\hline $1 . \quad \begin{array}{l}\text { I ask HLs to provide oral input in Spanish -opinions, } \\
\text { descriptions, comments, stories, etc. to promote } \\
\text { listening comprehension among their L2 peers. (Input } \\
\text { provider) }\end{array}$ & 2.36 & .73 \\
\hline $\begin{array}{l}\text { I ask HLs to provide written input in Spanish -opinions, } \\
\text { descriptions, comments, stories, etc.- to promote reading } \\
\text { comprehension among their L2 peers. (Input provider) }\end{array}$ & 1.95 & .57 \\
\hline $3 . \quad \begin{array}{l}\text { I ask HLs to serve as an example of good Spanish } \\
\text { pronunciation to the class. (Linguistic model) }\end{array}$ & 2.59 & .85 \\
\hline
\end{tabular}




\begin{tabular}{|c|c|c|}
\hline $\begin{array}{l}\text { 4. I ask HLs to pronounce new words and forms in Spanish } \\
\text { to make the class aware of regional differences in Spanish } \\
\text { pronunciation. (Linguistic model) }\end{array}$ & 2.5 & .8 \\
\hline $\begin{array}{l}\text { 5. I ask HLs to share with the class the vocabulary they use } \\
\text { in their home Spanish variety. (Linguistic informant) }\end{array}$ & 2.90 & .81 \\
\hline $\begin{array}{l}\text { 6. I ask HLs to share with the class the grammatical forms } \\
\text { they use in their home Spanish variety. (Linguistic } \\
\text { informant) }\end{array}$ & 1.91 & .51 \\
\hline $\begin{array}{l}\text { 7. I ask HLs to talk about their heritage culture in class. } \\
\text { (Cultural informant) }\end{array}$ & 2.59 & .85 \\
\hline $\begin{array}{l}\text { 8. I believe HLs like to talk about their heritage culture in } \\
\text { class. (Cultural informant) }\end{array}$ & 3.05 & .58 \\
\hline $\begin{array}{l}\text { 9. I ask HLs to inform about the appropriate use of words } \\
\text { (e.g., viejita) or forms (e.g., vos) in their home Spanish } \\
\text { variety. (Pragmatic informant) }\end{array}$ & 2.68 & .71 \\
\hline $\begin{array}{l}\text { 10. I ask HLs to translate my directions or explanations into } \\
\text { English for their L2 peers. (Translator/interpreter) }\end{array}$ & 2.27 & .83 \\
\hline $\begin{array}{l}\text { 11. During pair or group work, I ask HLs to help/tutor their } \\
\text { L2 peers. (Tutor/helper) }\end{array}$ & 2.55 & .67 \\
\hline $\begin{array}{l}\text { 12. I ask HLs to help me correct their L2 peer work in class. } \\
\text { (Tutor/helper) }\end{array}$ & 2.07 & .97 \\
\hline
\end{tabular}

Note: $1=$ Totally disagree; 2 = Disagree; $3=$ Agree; $4=$ Totally agree.

As observed in Table 2, the questionnaire data pointed to the assignment of the following roles (i.e., Average at 2.5 or beyond): Linguistic model; linguistic, cultural and pragmatic informant; and tutor/helper. In order to have a clear picture of the roles assigned to HLs by their instructors, the questionnaire information was further analyzed by role and compared with qualitative evidence from the interviews and class observations.

a). Input provider: For this role, instructors disagreed with the statements about the assignment of the role of input provider, item $1(\mathrm{M}=2.36 ; \mathrm{SD}=.73)$ and item $2(\mathrm{M}=1.95 ; \mathrm{SD}=.57)$. Also, they did not provide comments about this role during the interview, nor was it identified during the class observation.

b). Linguistic model: HLs could be asked to serve as linguistic models for the rest of the learners in a mixed class. Instructors in this study somewhat agreed with the statements referring to this role: item 3 ("I ask HLs to serve 
as an example of good Spanish pronunciation to the class."), and item 4 ("I ask HLs to pronounce new words and forms in Spanish to make the class aware of regional differences in Spanish pronunciation."). For both items, the average was around 2.5 on the 4-point Likert scale. Although this role was not identified during the class observations, five instructors' comments during the interviews provided evidence of this role assignment. For example, Instructor 8 commented: "I like the fact that they have good pronunciation, so they help the class to see other pronunciations."

c). Linguistic informant: Participating instructors assigned the role of linguistic informant to the HLs in their beginner classes. From the questionnaire, instructors somewhat agreed with assigning the role of linguistic informant for vocabulary (item 5: "I ask HLs to share with the class the vocabulary they use in their home Spanish variety.": $\mathrm{M}=2.90 ; \mathrm{SD}=.81$ ), but disagreed on using HLs as informants about grammar (item 6: "I ask HLs to share with the class the grammatical forms they use in their home Spanish variety": $\mathrm{M}=$ $1.91 ; \mathrm{SD}=0.51)$.

Five instructors' comments revealed they assigned this role, especially in regards to vocabulary. For instance, Instructor 19 said: "I may ask them if they say something differently." This role was also identified twice during the class observations. In the first instance, Instructor 20 asked a HL about a grammatical form: "icuándo usas ir a y cuándo usas el futuro? - tr. When do you use going to vs. future?" In the second instance, Instructor 13 asked a HL how a Spanish word was said in his heritage variety: "icómo se dice belado en México? - tr. How do you say ice cream in Mexico?"

d). Cultural informant: The role of cultural informant was frequently assigned to HLs. Instructors agreed with item 7 (I ask HLs to talk about their heritage culture in class. $\mathrm{M}=2.59 ; \mathrm{SD}=.85$ ) and item 8 (I believe HLs like to talk about their heritage culture in class. $\mathrm{M}=3.05 ; \mathrm{SD}=.58$ ) from the questionnaire. Eight instructors also commented that one of the advantages of having HLs in their classes was that they could provide cultural information. For example, Instructor 12 commented "I could use them more with the culture in class." while Instructor 20 pointed out that HLs: "Tienen la oportunidad de derribar los estereotipos sobre los hablantes del español y su cultura" (tr. They have the chance to change the stereotypes about Spanish speakers and their culture). This role was also identified in six of the eleven class observations 
conducted (Instructor to HL: “¿Cuáles son los ingredientes de los chilaquiles?” tr. What are the ingredients of chilaquiles?).

e). Pragmatic informant: Instructors seem to assign the role of pragmatic informants to HLs. Although no comments in the interviews were related to this role, instructors agreed with item 9: I ask HLs to inform about the appropriate use of words (e.g., viejita) or forms (e.g., vos) in their home Spanish variety $(\mathrm{M}=2.68 ; \mathrm{SD}=.71)$, and this role was identified in one of the class observations (Instructor to HL: "¿Con quién usas "Me podrías?" tr. With whom do you use "Me podrías?).

f). Translator/Interpreter: Instructors assigned HLs the role of translators in their beginner classes. Although they disagreed with questionnaire item 10: "I ask HLs to translate my directions or explanations into English for their L2 peers." $(\mathrm{M}=2.27 ; \mathrm{SD}=.83)$, evidence from the interviews and the classroom observations showed the contrary. Two instructors stated that they used the HLs to translate Spanish information into English for the class (Instructor 17: "Ellos responden a las preguntas de cómo se dice esto en inglés." - tr. They answer questions about how to say this in English.), and three instances of this role were identified during the class observations (e.g., Instructor to HL: "iPuedes decir las instrucciones en inglés?" - tr. Could you say the instructions in English?).

g). Tutor/Helper: The role of tutor/helper was perceived as one of the advantages of having HLs in mixed beginner classes. Six instructors commented on assigning this role to HLs in their classes (Instructor 9: "Les he pedido que ayuden a sus compañeros con las actividades." - tr. I have asked them to help their classmates with the activities). Instructors also agreed with item 11: "During pair or group work, I ask HLs to help/tutor their L2 peers." ( $M=2.55$ $; \mathrm{SD}=.67)$, but they did not agree that they asked HLs to help them correct other students' work in class (item 12: $\mathrm{M}=2.07 ; \mathrm{SD}=.97$ ).

As to how instructors perceived whether these roles support or inhibit the HL language instruction goals and meet their needs for cultural connection, comments from the interviews offered some insights into the matter. For example, instructors 5 and 20 commented that, depending on their proficiency level, HLs liked helping others students that are not HLs. Other instructors (6 and 9) believed that HLs could reinforce or improve their Spanish by participating and helping other students in the class. Instructor 8 highlighted the fact that HLs liked to 
contribute to the class because they felt proud about their heritage and they wanted to share it with others.

Although some instructors commented on the benefits of assigning HLs these roles in class, some others recognize that HLs could feel uncomfortable or ashamed to say things in Spanish because they did not feel prepared (Instructors 10 and 11). To avoid these situations, some instructors (e.g., Instructor 8) clarified that they never asked HLs to contribute with specific information to the class, but they let the HLs volunteer linguistic and cultural information they wanted to share with their classmates. Instructor 16 explained that, in some cases, HLs could not be asked about grammar because they did not have the necessary metalinguistic knowledge about Spanish to explain any rules.

\section{Discussion}

Findings from interviews, class observations and questionnaires indicate that teachers assign multiple roles to the Spanish HLs in beginner mixed classes at the college level. The three sources of information show that teachers mostly ask their HLs to be linguistic and cultural informants in class. Teachers usually ask HLs to provide vocabulary, expressions or some linguistic forms related to the Spanish variety that they speak at home or in their community. The assignment of this role could have a positive impact on HLs' motivation towards their use of the heritage language because their language variety is being validated in the class and used as a springboard to learn more formal or academic language (Potowski \& Lynch, 2014).

Being a cultural informant could also contribute to having more active HLs in a mixed class while they are fulfilling their needs to connect with their heritage culture. Although mixed classes are not usually recommended for HLs, Carreira (2014) suggests the implementation of an approach to mixed classes in which topics related to HLs' bilingual and bicultural identity are discussed by incorporating the cultural and linguistic expertise that they already have.

It is important to mention that some teachers may hesitate to ask HLs aboutgrammar rules given their lack of metalinguistic knowledge, linguistic confidence or low Spanish proficiency. In some cases, these students have never taken a formal Spanish class, but rather relied only on the Spanish exposure they have had at home. As a consequence, they are not able to talk about the language or explain how different grammar aspects work. From the affective point of view, HLs could feel that being assigned the role of linguistic informant can create false expectations about their Spanish proficiency. Potowski (2002), 
for example, pointed out that in her study, some HLs felt uncomfortable when they were asked to provide linguistic or cultural information in class and that they could not perform this role. Similarly, in Felix's study (2009), the HLs felt that they did not belong in the mixed class. Specially, after the teacher created false expectations about them being competent speakers of Spanish. In consequence, their L2 classmates might have thought that they should not be in the class. Their classmates could have also thought that the HLs were taking the class to get a high grade without much effort.

Other roles that are assigned to HLs are those of being a linguistic model and a pragmatic informant. For these two roles, only two sources of information provided evidence of HLs actually being asked to model language, especially pronunciation, for the class, or provide information about the appropriate use of certain linguistic forms in their Spanish context of use. Both roles may assume that the HLs have advanced productive skills in the language when it may not be the case for these learners. Valdés (2001) explains that the bilingual continuum among the HLs is diverse, so it is common that in the same class we could find HLs that are only able to understand the oral and written heritage language in familiar contexts (receptive bilinguals) and other HLs with an advanced language competence who need to develop their language skills in more formal or academic contexts. In beginner Spanish mixed classes, we may find a large number of receptive bilinguals, so to assume that they have advanced Spanish proficiency could result in negative consequences for the HLs' linguistic confidence. Potowski (2002) argues that posing HLs as linguistic models could cause a lowering of their self-esteem as speakers of the heritage language and decrease their motivation to study the language.

The presence of the HLs is also valued by teachers in the mixed classroom because they can play roles such as translators/interpreters, and tutors for other students in class, as found in Felix's study (2009). On some occasions, teachers, especially those whose Spanish was their L2, could ask HLs to give the Spanish translation of what they said in English. Other instructors whose L2 is not that strong could request the HL to translate their instructions from Spanish into English to benefit the L2 beginner students. Even though HLs may be used to this role in familiar and personal contexts and have positive attitudes towards translation (Gasca, 2017), it is important to consider that, as with the other roles, the effects on HLs' confidence and motivation towards translation would depend on the level of the HLs' proficiency in the heritage language. It could help HLs increase their linguistic confidence if they are able to perform the role without problems, or it could reinforce the perception of having limitations with their Spanish. This practice can also be misleading in making students, HLs and L2s, believe that anybody speaking two languages can serve as translator when translation involves having not only knowledge 
of the target language, but also knowledge about the text-type, the source language, the real-world, and the linguistic differences between the two languages (Bell, 1991).

As it has been observed in previous studies (Belpoliti, 2017; Bowels \& Montrul, 2014; Campanaro, 2013; Dones-Herrera, 2015; Felix, 2009; Russel \& Kuriscak, 2015), some evidence showed that HLs in mixed classes are assigned the role of tutor/helper. Potowski (2002) suggests that HLs may feel at a disadvantage in comparison with the L2 students because they do not have the same knowledge of the grammar rules that the L2 learners have. Taking this situation into account, HLs may feel that they are unprepared to perform the tutor role in classes that are heavily focused on grammar rules or in which language use is explained with linguistic grammar terminology. On the other hand, HLs may feel empowered when helping other students with certain words or completing activities in the classroom (Felix, 2009). Also, it may be the case that tutoring could provide opportunities to encourage interactions between HLs and L2 learners that support the growth of not only L2 learners, but also the HLs, as observed in advanced mixed language classes (Edstrom, 2007).

In this study, no evidence was found for the role of input provider. It does not seem that teachers at beginning levels ask the HLs to produce oral or written Spanish so that L2 students can analyze the language or answer questions about the content of the HLs' messages. Although this role was suggested by the annotations of HLs in introductory Spanish textbooks in Asención-Delaney's study (2019), the actual Spanish instructors in this study did not consider the HLs as a source of Spanish language in the mixed classes. It seems that the instructors in this study do not believe that the comprehension skills of the L2 learners could directly benefit as a result of their interactions with the HLs, as suggested in other studies in advanced mixed classes, such as the one by Edstrom (2007).

\section{Conclusions}

Spanish instructors seem to assign multiple roles to HLs in beginning mixed classes. HLs could be asked to provide information about the language variety they speak, for example, alternative ways of saying a word or expression, and the cultural practices of their heritage groups. These roles could help validate the HLs' language varieties in the class and pose them as experts in the classroom. Other roles that may be assigned include a tutor, translator, pragmatic informant, and linguistic model. No evidence was found to support the belief that teachers assign HLs the role of input provider in the mixed classroom. It is worth mentioning that depending on the HLs' proficiency in the heritage language, these roles could support or inhibit students' goals at pursuing further education in their heritage language. 
These findings have particular implications for language teacher training and professional development. In preparation for dealing with the complexities involved in teaching mixed language classes, some researchers and practitioners suggest the implementation of a new kind of language teaching preparation program that targets HL education either in mixed classes or in HL classes. This training can take the form of another teaching methods course, modules, or workshops for in-service teachers addressing the needs of this learner population in Spanish L2 classes (Belpoliti, 2017; George \& Salgado-Robles, 2018). Lacorte (2016) suggests training opportunities in which teachers could develop effective skills, dispositions and attitudes such as the understanding of the historical, cultural, sociolinguistic, and academic backgrounds of HLs, awareness about the distribution of language proficiency across modalities and skills among HLs, pedagogical strategies to encourage collaboration among HL and L2 students, classroom management strategies in mixed classes, and awareness of beliefs and attitudes regarding HLs and their varieties.

Finally, although this study provides initial insights into the roles of HLs in beginner mixed classes, it did not seek to judge teachers' motivation when assigning these roles to their HLs in their classes. Factors affecting teaching practices could be rooted in teachers' personal characteristics such as HL proficiency, teaching experience, and professional training. Therefore, more research is needed to understand teachers' cognition and motivations in relation to the roles they assign to HL students in beginner mixed classes. In addition, due to limitations on the number of instructors surveyed/observed and the education context researched, it is not possible to generalize these findings to all instructors in beginner Spanish mixed classes at the elementary, secondary, and tertiary levels. It is also important to mention that the impact that these role assignments may have on this student population should be further investigated from the students' point of view in order to make teachers aware of the complexities reflected in HLs' diverse linguistic and cultural needs, goals, and affective responses to heritage language instruction in mixed language classes.

\section{References}

Al Masaeed, K.B. (2014). The ideology of U.S. Spanish in foreign and heritage language curricula: Insights from textbooks and instructor focus groups. (Unpublished Ph.D. dissertation). Doctoral Program in Second Language Acquisition and Teaching. The University of Arizona. 
Asención-Delaney, Y. (2019). Anotaciones para hablantes de herencia en libros de texto de español a nivel introductorio. In G. Thompson \& S. Alvord (Eds.), Contact, community and connections. Current approaches to Spanish in multilingual populations (pp. 381400). Delaware: Vernon Press.

Beaudrie, S. (2009). Receptive bilinguals' language development in the classroom: The differential effects of heritage versus foreign language curriculum. In M. Lacorte \& J. Leeman (Eds.), Español en Estados Unidos y otros contextos de contacto: Sociolingüística, ideología y pedagogía (pp. 325-345). Madrid: Vervuert. https://doi.org/10.31819/9783865279033017

Beaudrie, S. (2012). Research on university-based Spanish heritage language programs in the United States: The current state of affairs. In S. Beaudrie \& M. Fairclough (Eds.), Spanish as a Heritage Language in the United States: State of the field (pp. 203-21). Washington, DC: Georgetown University Press.

Beaudrie, S. \& Ducar, C. (2005). Beginning level university heritage programs: Creating a space for all heritage language learners. Heritage Language Journal, 3(1), 1-26.

Bell, R. (1991). Translation and translating. London: Longman.

Bello, A. (2014). Spanish instructors and heritage language learners' perception. (Unpublished Master's paper). University of Illinois at Urbana-Champaign.

Belpoliti, F. (2017). No teacher left behind? Teachers in the context of Spanish as Heritage language in North Texas: profiles, perspectives and needs. Presentation in American Association of Teachers of Spanish and Portuguese Annual Conference. Chicago, IL.

Blake, R. \& Zyzik, E. (2003). Who's helping whom?: Learner-Heritage-speakers' networked discussions in Spanish. Applied Linguistics, 24(4), 519-544. https://doi.org/10.1093/ applin/24.4.519

Bowles, M. (2011). Exploring the role of modality: L2-Heritage learner interactions in the Spanish language classroom. Heritage Language Learning, 8(1), 30-65.

Bowels, M. \& Montrul, S. (2014). Heritage Spanish speakers in university language courses: A decade of difference. ADFL Bulletin, 43(1), 112-122. https://doi.org/10.1632/ adfl.43.1.112

Boyd, R. (2000). Attitudes of teachers of Spanish as a foreign language towards teaching Spanish to Hispanic students. Retrieved from http://files.eric.ed.gov/fulltext/ED473833. pdf 
Burgo, C. (2019). Mixed classrooms: How do Spanish heritage speakers feel about the mix? In G. Thompson \& S. Alvord (Eds.), Contact, community and connections. Current approaches to Spanish in multilingual populations (pp. 305-322). Delaware: Vernon Press.

Campanaro, T. G. (2013). Spanish heritage speakers and second language learners in mixed classrooms: Perceptions of students and instructors. (Unpublished Master's thesis). Master of Arts in Applied Linguistics. University of Alberta. Edmond, Alberta.

Carreira, M. (2014). Teaching heritage language learners: A study of program profiles, practices and needs. In A. Themistoklis \& P. Trifonas (Eds.), Rethinking beritage language education (pp. 20-44). Cambridge: CUP.

Dones-Herrera, V. (2015). Heritage vs. non-heritage language learner attitudes in a beginninglevel mixed Spanish language class. (Unpublished Master's thesis). Spanish Master in Arts. The University of Arizona.

Edstrom, A. (2007). The mixing of non-native, heritage, and native speakers in upper-level Spanish courses: A sampling of student opinion. Hispania, 90(4), 755-768. https://doi. org/10.2307/20063610

Felix, A. (2009). The adult heritage Spanish speaker in the foreign language classroom: a phenomenography. International Journal of Qualitative Studies in Education, 22(2), 145-162. https://doi.org/10.1080/09518390802703414

Gasca, L. (2017). La traducción y la enseñanza de lenguas de herencia: una aproximación a la experiencia traductora (EN-ES) de hispanohablantes bilingües en los Estados Unidos. En E. Nebot \& J. Jiménez-Salcedo (Eds.), Las lenguas minorizadas en el orden postmonoligüe (pp. 89-103). Castelló de la Plana: Universitat Jaume Publications.

George, A. \& Salgado-Robles, F. (2018). Raising awareness about heritage language learners in the L2 Spanish classroom: Teacher beliefs and attitudes. La toma de conciencia sobre el aprendiz de lengua de herencia en clases de español como segunda lengua: Creencias y actitudes del profesor. Estudios de Lingüística Inglesa Aplicada, 18, 157-181. https:// doi.org/10.12795/elia.2018.i18.07

Lacorte, M. (2016). Teacher development in heritage language education. In M. Fairclough \& S. Beaudrie (Eds.), Innovative strategies for heritage language teaching (pp. 99-119). Washington, DC.: Georgetown University Press.

Lacorte, M. \& Canabal, E. (2005). Teacher beliefs and practices in advanced Spanish classrooms. Heritage Language Journal, 3(1), 83-107. 
Leeman, J. \& Serafini, E. (2017). Student perceptions of deficit and difference in 'mixed' HL/ L2 classes. Presentation at the Symposium on Spanish as a Heritage Language. University of California, Irvine.

National Center for Education Statistics [NCES]. (2017). Status and trends in the education of racial and ethnic groups 2017. NCES Report 2017-051. Washington, D.C: US Government Printing Office. Retrieved from https://nces.ed.gov/pubs2017/2017051.pdf

Potowski, K. (2002). Experiences of Spanish heritage speakers in university foreign language courses and implications for teacher training. ADFL Bulletin, 33(3), 35-42https://doi. org/10.1632/adfl.33.3.35

Potowski, K. \& Lynch, A. (2014). Perspectivas sobre la enseñanza del español a los hablantes de herencia en los Estados Unidos. Journal of Spanish Language Teaching, 1(2), 154-170. https://doi.org/10.1080/23247797.2014.970360

Randolph, L. Jr. (2017). Heritage language learners in mixed Spanish classes: subtractive practices and perceptions of high school Spanish teachers. Hispania, 100(2), 274-288. https://doi. org/10.1353/hpn.2017.0040

Rosa, J. (2019). Looking like a language, sounding like a race. Raciolinguistic ideology and the learning of Latinidad. Oxford: Oxford University Press. https://doi.org/10.1093/ oso/9780190634728.001.0001

Russell, B. D. \& Kuriscak, L. M. (2015). High school Spanish teachers' attitudes and practices toward Spanish heritage language learners. Foreign Language Annals, 48(3), 413-33. https://doi.org/10.1111/flan.12145

Valdés, G. (2001). Heritage language students: Profiles and possibilities. In J. Peyton, D. Ranards \& S. McGinnis (Eds.), Heritage languages in America: Preserving a national resource (pp. 37-77). Washington, DC: Center for Applied Linguistics and Delta Systems. 